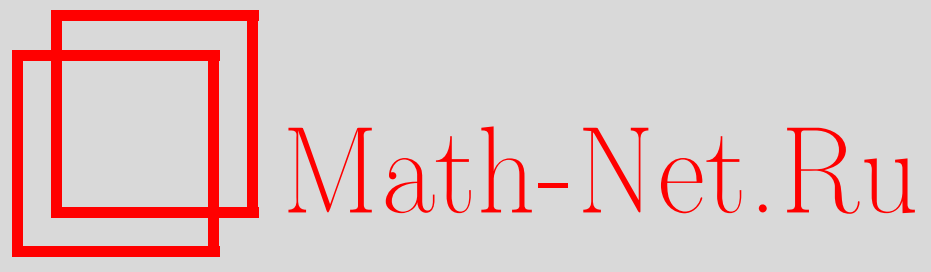

В. П. Маслов, Чему я научился у Б. М. Левитана, $M a-$ тем. заметки, 2014, том 96, выпуск 1, 3-4

DOI: https://doi.org/10.4213/mzm10497

Использование Общероссийского математического портала Math-Net.Ru подразумевает, что вы прочитали и согласны с пользовательским соглашением http://www . mathnet.ru/rus/agreement

Параметры загрузки:

IP : 52.23 .180 .231

26 апреля 2023 г., 16:10:08

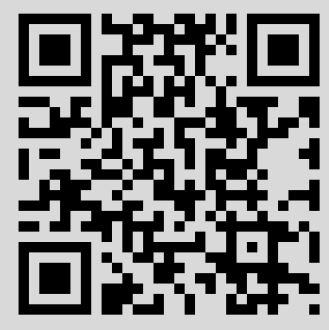




\section{Чему я научился у Б. М. Левитана}

\section{В. П. Маслов}

K 100-летию Бориса Моисеевича Левитана

Влияние, которое оказал Борис Моисеевич Левитан на наше поколение математиков, невозможно ни описать, ни измерить. Я приведу только один эпизод, который изменил мое мировоззрение как представителя следующего поколения.

Известный математик Титчмарш решал задачу о втором члене асимптотики для одномерного оператора Шредингера и решил ее лишь в случае, когда потенциал равен $x^{4}$ и $x^{6}[1]$. В начале 60 -х гг. я решил эту задачу в общем случае другим методом и выступил с решением на заседании Московского математического общества. Б. М. Левитан, крупнейший специалист в этой области, настолько не поверил, что это возможно, что не стал слушать мое доказательство. Дело в том, что рассказывал я довольно плохо, а квантово-механический язык для математиков старшего поколения был непривычен.

Я сообщил об этом априорном недоверии представителя старшего поколения самому молодому члену редколлегии журнала "Функциональный анализ", блестящему и уже знаменитому математику, остротой ума и резкостью дискуссий которого как я, так и все мои знакомые дружно восхищались. Он сказал: "Надо давать сражение на их территории. Когда Левитан подаст статью в наш журнал, я предложу послать ее на отзыв В. П. Маслову. А уж отзыв надо написать быстро и так, чтобы мы как статью, так и отзыв опубликовали в одном номере."

Задача была поставлена нетривиальная, безусловно, заслуживающая быть именной. Но так как она не совсем математическая, то имя автора постановки задачи я не буду называть. Но постановка, прямо скажем, нестандартная.

Как порешили, так и сделали. Я был в роли Левши, которому велено было подковать блоху. Подковать-то я подковал, но блоха, как в рассказе Лескова, прыгать перестала: Борисом Моисеевичем были приведены простые и красивые достаточные условия дискретности спектра системы уравнений [2], я же привел критерий (необходимые и достаточные условия) очень сложной довольно некрасивой конструкции [3].

Левитан, тем не менее, был в полном восторге. Я увидел, что настоящий математик радуется продвижению в науке независимо от того, кто его совершил. "Как Вы догадались?" - допытывался у меня Борис Моисеевич. Я, конечно, не признался ему, что бо̀льшая часть успеха принадлежит математику, поставившему исходную задачу - вгрызться в его работу.

В дальнейшем мы с Борисом Моисеевичем много обсуждали тонкие оттенки доказательства предложенного критерия. Эти беседы произвели в моем мировоззрении своего рода переворот. Я вообще прекратил делать какие-либо выступления или писать статьи в защиту своего приоритета или укрепления моего реноме как математика. Например, президент математического конгресса в Ницце $(1970$ г.) великий Жан Лере знал, что концепция Фурье интегральных операторов, изложенная Хермандером на этом конгрессе, ничем не отличается от моей статьи в ДАН 1967 г. [4]. Он предложил мне написать об этом в трудах конгресса. Но я уже научился подавлять в себе элементы тщеславия. Я понял, что надо радоваться успехам в науке, - это главное для истинного ученого. Более того, необходимо это замечательное отношение к науке Бориса Моисеевича стараться привить следующему поколению российских ученых.

DOI: $10.4213 / \mathrm{mzm} 10497$ 


\section{СПИСОК ЦИТИРОВАННОЙ ЛИТЕРАТУРЫ}

[1] E. C. Titchmarsh, Eigenfunction Expansions Associated with Second-order Differential Equations, Clarendon Press, Oxford, 1946. [2] Б. М. Левитан, Г. А. Суворченкова, Функи. анализ и его прил., 2:2 (1968), 56-62. [3] В.П. Маслов, Функи. анализ и его прил., 2:2 (1968), 63-67. [4] В. П. Маслов, Докл. АН СССР, 177:6 (1967), 1277-1280.

В. П. Маслов

Национальный исследовательский

университет «Высшая школа экономики», г. Москва
Поступило

20.05 .2014 